\title{
FAILURE OF CLOMIPHENE TO INTERRUPT GESTATION IN RATS TREATED WITH RESERPINE*
}

\author{
T. GUPTA, K. SENGUPTA AND A. GHATTERJEE \\ Department of Physiology, Raja Peary Mohan College, \\ Uttarpara, Hooghly, West Bengal 712258, India
}

(Received 7th March 1974)

\begin{abstract}
Summary. Injections of clomiphene $(3.0 \mathrm{mg} / \mathrm{kg})$ on Days $12,14,16$ and 18 of pregnancy induced complete resorption of fetuses, a polyfollicular state of the ovary and luteolysis in rats. If reserpine was given at the same time as clomiphene, pregnancy was maintained and the status of the fetuses, placentae, ovaries and corpora lutea resembled that found in control rats. The fetal survival rate $(96.7 \%)$ was found to be almost identical with that of the controls $(97.9 \%)$. It is suggested that abnormal stimulation of the pituitary FSH and LH may possibly be the primary cause of the clomiphene-induced interruption of pregnancy in rats.
\end{abstract}

\section{INTRODUCTION}

Clomiphene citrate (Clomid), an analogue of the non-steroidal oestrogen chlorotrianisene (or TACE), has been shown to be an effective stimulus for the induction of ovulation in non-ovulating women (Greenblatt, 1961) and also in experimentally induced anovulatory rats (Döcke, 1969). Some authors have claimed that Clomid acts by stimulating an endogenous release of gonadotrophin (Roy, Greenblatt, Mahesh \& Junqck, 1963; Riley \& Evans, 1964; Boyar, 1970) while others have reported that Clomid inhibits gonadotrophin secretion (Holtkamp, Greslin, Root \& Lerner, 1960). In animals, the paradoxical effect of Clomid on the endogenous release of gonadotrophin has been shown to depend on the experimental design and the dosage used (Baier \& Taubert, 1969; Döcke, 1969; Boyar, 1970). Though the antifertility effect of Clomid in laboratory animals is consistent, its mechanism of action is still in dispute (Segal \& Nelson, 1961; Staples, 1966). The present study was designed to evaluate whether the action of Clomid in the interruption of gestation could be reversed by reserpine, a compound capable of blocking the action of pituitary gonadotrophins (Ghatterjee \& Harper, 1970).

\section{MATERIALS AND METHODS}

Thirty-two colony-bred virgin albino rats weighing 140 to $150 \mathrm{~g}$ were used. They were exposed to a controlled lighting schedule (12 hr light/12 hr dark)

* Reprint requests to $\mathrm{Dr} \mathrm{A}$. Chatterjee. 


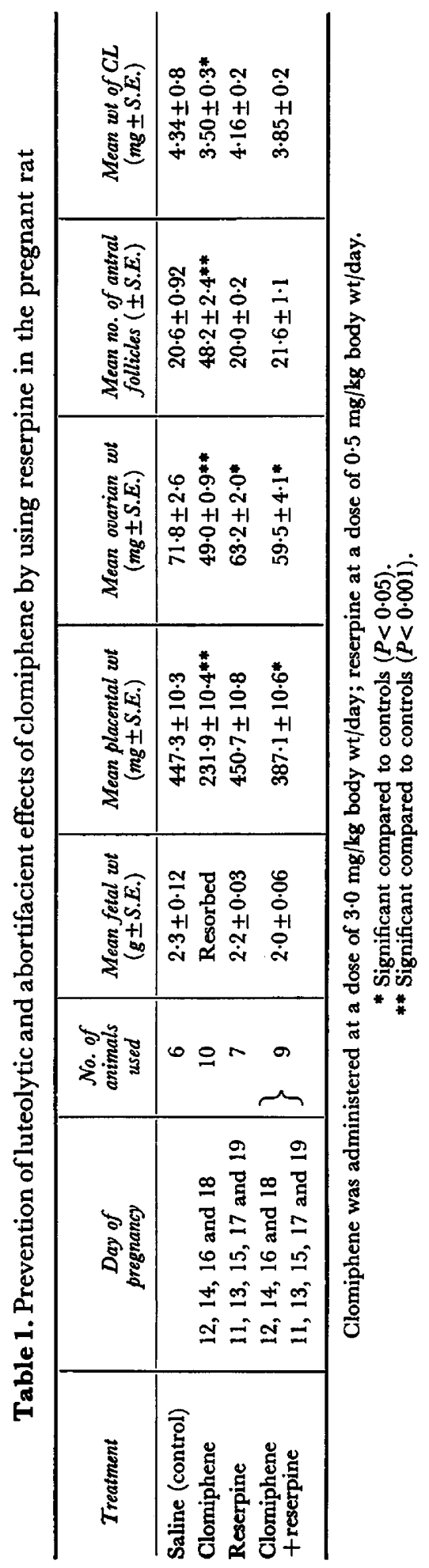


and had free access to balanced food pellets and water. Daily vaginal smears were obtained from cyclic animals and the constancy of the cycle was confirmed before the animals were used. On the evening of the day of vaginal pro-oestrus, the females were caged with males of proven fertility. The day on which spermatozoa were found in the vaginal smear or vaginal plugs were found was designated Day 1 of pregnancy. The pregnant rats were allotted to groups according to the treatment schedule (Table 1).

Clomid was suspended in $0.9 \%$ sterile saline and injected subcutaneously at a dose level of $3.0 \mathrm{mg} / \mathrm{kg}$ body weight/day. Reserpine (Serpasil) was injected subcutaneously in a dose of $0.5 \mathrm{mg} / \mathrm{kg}$ body weight/day. The rats were lightly anaesthetized with ether on Day 9 of pregnancy and the uteri were examined for the presence of implantation sites through a mid-ventral incision. At autopsy on Day 20, fetuses, placentae, ovaries and corpora lutea were dissected out, weighed and compared with those of the controls using Student's $t$ test. The condition of the ovaries was assessed histologically.

\section{RESULTS}

Injections of Clomid on Days 12, 14, 16 and 18 of pregnancy caused complete resorption of fetuses, leaving the regressing placentae at the sites of their attachment in the uteri. The mean weight of the regressed placentae was 231.9 $\pm 10.4 \mathrm{mg}$ compared with $447.3 \pm 10.3 \mathrm{mg}$ in the controls. The weights of the ovaries and individual corpora lutea were also significantly reduced (Table 1). Histology revealed an ovarian polyfollicular state $(P<0.001)$ associated with luteolysis of the corpora lutea of gestation.

Treatment with reserpine concurrently with Glomid consistently reversed the deleterious effect of Clomid and pregnancy was maintained. Although the mean weights of the placentae $(387 \cdot 1 \pm 10.6 \mathrm{mg}$ versus $447 \cdot 3 \pm 10 \cdot 3 \mathrm{mg})$ and ovaries $(59 \cdot 5 \pm 4 \cdot 1 \mathrm{mg}$ versus $71 \cdot 8 \pm 2 \cdot 6 \mathrm{mg})$ were reduced significantly compared to those of the controls, the fetal survival rate $(96.7 \%$ versus $97.9 \%)$ and the weight of the fetuses $(2.0 \pm 0.06 \mathrm{~g}$ versus $2.3 \pm 0.12 \mathrm{~g})$ showed no alteration (Tables 1 and 2). The polyfollicular state and luteolysis recorded after Clomid therapy were not found in the ovaries of animals treated with reserpine in addition to Clomid (Table 1).

Table 2. Reserpine and reversal of the detrimental effect of clomiphene on the fetal survival rate

\begin{tabular}{|c|c|c|c|c|c|}
\hline Treatment & $\begin{array}{c}\text { Day of } \\
\text { pregnancy }\end{array}$ & $\begin{array}{c}\text { No. of } \\
\text { animals } \\
\text { used }\end{array}$ & $\begin{array}{c}\text { No. of implantation } \\
\text { sites at laparotomy } \\
\text { on Day } 9\end{array}$ & $\begin{array}{c}\text { No. of fetuses } \\
\text { at autopsy }\end{array}$ & $\begin{array}{c}\text { Survival rate } \\
\text { of fetuses } \\
(\%)\end{array}$ \\
\hline Saline (control) & & 6 & 48 & 47 & $97 \cdot 9$ \\
\hline Glomiphene & $12,14,16$ and 18 & 8 & 65 & 0 & 0 \\
\hline Reserpine & $11,13,15,17$ and 19 & 6 & 47 & 47 & 100 \\
\hline $\begin{array}{l}\text { Clomiphene } \\
+ \text { reserpine }\end{array}$ & $\begin{array}{l}12,14,16 \text { and } 18 \\
11,13,15,17 \text { and } 19\end{array}$ & \} 7 & 60 & 58 & $96 \cdot 7$ \\
\hline
\end{tabular}




\section{DISCUSSION}

The abnormal ovarian follicular development observed in the pregnant rat treated with Clomid is in agreement with the previous findings where Clomid has been shown to reduce the hypothalamic FSH-releasing factor (Baier \& Taubert, 1969) with a corresponding increase in plasma FSH activity in rats (Igarashi \& co-authors, 1967; Baier \& Taubert, 1968) as well as in man (Bardin, Ross \& Lipsett, 1967; Faiman \& Ryan, 1968). There are conflicting reports, however, regarding the direct stimulatory effect of Clomid at the ovarian level (Smith, Smith \& Kistner, 1963; Mellinger, 1966). The histological evidence of an over-stimulation of the follicular apparatus in the Clomidtreated ovaries and its reversal by reserpine does not exclusively support the view of a direct ovarian stimulation in vivo by Clomid since reserpine at our selected dose level does not alter the ovarian sensitivity to gonadotrophic stimulation (Chatterjee \& Harper, 1970). It has been clearly shown (Chatterjee, Gupta \& Sengupta, 1974) that exogenous progesterone or prolactin are able to prevent the abortifacient effect of Clomid and the ovarian changes characteristically found following treatment with Clomid in pregnancy. It seems possible that the deleterious effect of Clomid in interrupting pregnancy may be mediated through an excessive production of endogenous FSH and possibly of LH. Injections of PMSG, primarily a long-acting FSH, also cause almost identical ovarian abnormalities and induce abortion as recorded after Clomid treatment in the pregnant rat (A. Chatterjee, T. Gupta \& A. Pal, unpublished observations).

\section{ACKNOWLEDGMENTS}

This research work was supported by the grants from the Indian Council of Medical Research to A.C. and the University Grants Commission, New Delhi, to T.G. The co-operation of Mr R. K. Bhattacharya of the Department of Physiology, University College of Science and Technology, Calcutta, is gratefully acknowledged. The vitamin preparation (Protovit) used in this study was kindly furnished through Dr B. Dutt of Roche Products Ltd, Bombay, India. Glomid was kindly donated by W. M. S. Merrell \& Company, Cincinnati, Ohio, U.S.A. Serpasil was kindly donated by Ciba of India Ltd, Bombay, India.

\section{REFERENGES}

Baier, H. \& Taubert, H. D. (1968) FSH-releasing effect of clomiphene in the female rat. Experientia, 24, 1165.

Bater, H. \& TAuBert, H. D. (1969) Effect of clomiphene upon plasma FSH-activity and hypothalamic FSH-RF content in ovariectomized estrogen-progesterone blocked rats. Endocrinology, 84, 946.

Bardin, G. W., Ross, G. T. \& Lipsett, M. B. (1967) Site of action of clomiphene citrate in men: a study of the pituitary-Leydig cell axis. F. clin. Endocr. Metab. 27, 1558.

Boyar, R. M. (1970) Effects of clomiphene citrate on pituitary FSH, FSH-RF, and release of LH in immature and mature rats. Endocrinology, 629.

Chatterjee, A., Gupta, T. \& Sengupta, K. (1974) Possible mode of action of clomiphene. I. Reversal of clomiphene-induced interruption of decidual growth and gestation by prolactin or progesterone in rats. Acta endocr., Copenh. 75, 173. 
Ghatterjee, A. \& Harper, M. J. K. (1970) Interruption of implantation and gestation in rats by reserpine, chlorpromazine and ACTH: possible mode of action. Endocrinology, 87, 966.

Döcke, F. (1969) Ovulation-inducing action of clomiphene citrate in the rat. 7. Reprod. Fert. 18, 135.

Farman, G. \& RYAN, R. J. (1968) Effect of clomiphene isomers on follicle stimulating hormone (FSH) and luteinizing hormone (LH) in men. Proc. 3rd Int. Congr. Endocr., Mexico, Abstr. No. 466, p. 187. Excerpta med. Int. Congr. Ser. No. 157. Amsterdam.

Greenblatt, R. B. (1961) Ghemical induction of ovulation. Fert. Steril. 12, 402.

Holtkamp, D. E., Greslin, J. G., Root, G. A. \& LeRner, L. J. (1960) Gonadotrophin inhibiting and antifertility effects of clomiphene. Proc. Soc. exp. Biol. Med. 105, 197.

Igarashi, M., Ibuki, Y., Kubo, H., Kamoida, J., Yokota, N., Ybara, Y. \& Matsumoto, S. (1967) Mode and site of action of clomiphene. Am. F. Obstet. Gynec. 97, 120.

Mellinger, K. A. (1966) Proc. 5th Wld Congr. Fert. Steril., Stockholm.

RiLey, G. M. \& Evans, T. N. (1964) Effects of clomiphene citrate on anovulatory ovarian function. Am. J. Obstet. Gynec. 89, 97.

Roy, S., Greenblatt, R. B., Mahesh, V. B. \& Jungck, E. G. (1963) Clomiphene citrate: Further observations on its use in induction of ovulation in the human and on its mode of action. Fert. Steril. 14, 575.

Segal, S. J. \& Nelson, W. O. (1961) Antifertility action of chloramiphene. Anat. Rec. 139, 273.

Smrth, O. W., Smith, G. V. \& KistneR, R. W. (1963) Action of MER-25 and of clomiphene on the human ovary. F. Am. med. Ass. 184, 878.

StAPLES, R. E. (1966) Effects of clomiphene on blastocyst nidation in the rat. Endocrinology, 78, 82. 